\title{
THE “TERME DEL CORALLO” IN LIVORNO, ITALY, A CONTRIBUTION TO TRY GOING BEYOND THE ABANDON
}

\author{
G. Verdiani a, V. Fantini b \\ a Facoltà di Architettura di Firenze, via della Mattonaia, 14 Firenze, 50100 Italy - giorgio.verdiani@unifi.it \\ b Facoltà di Architettura di Firenze, via della Mattonaia, 14 Firenze, 50100 Italy - valentinafantini@virgilio.it
}

KEY WORDS: Baths, Livorno, Italia, Italy, Abandon, Terme, Liberty, Art Noveau, Photogrammetry, Digital Survey

\begin{abstract}
:
In Livorno, along the Mediterranean sea, in Italy, there is a terrific case of abandon, a historical monument made of fine art elements left to complete decay. The name of the place is "Terme del Corallo" and at its beginning it was a bath area exploiting the salt waters. After its first abandon, no serious efforts were done in years to come behind this situation, the poor and slow moves towards the restoration were stopped and slowed down by inefficiencies and infinite political considerations. The monument is now on the edge of collapse, showing a full failure of cultural preservation. According to this visible shame, a compact, almost viral, approach was started one year ago, entering the area in official (and less official) moments, a photogrammetric, photographical and direct survey was taken to document the condition of this monument. Further research was aimed to integrate and enhance the existing (poor) survey drawings and developing a restoration hypothesis recover to a solid, realistic and effective life to the whole monument. This paper will present the work made and the procedures, processing and results came out from this direct approach to this badly abandoned monument. The aim is to put in evidence this wrong situation, and to promote a sensitization about the correct choice to be taken for this monument before this rare artistic place from the XX Century will get completely lost.
\end{abstract}

\section{THE "TERME DEL CORALLO" BUILDING}

\subsection{The "bath age" in Italy}

Italy is one of the most important country for bathing-places in the world. Baths represent historical and cultural characteristics of a territory and one of the factors in social valuation and costumes. For example the "Thermae" and "Balnea" during the ancient roman period were centres for social life; or we may think about the "elite thermalism" during the beginning of the past Century .

The thermal bath was always strictly linked to the changes in the asset of a city. In time these buildings became part of the monumental and architectural heritage.

The first medicine treatise was "Corpus Ippocratium" written by Ippocrate, it's a meaningful text about the property of thermal water in human care. The phenomenon of thermalism had a big growth in ancient Rome. During the period of middle-age one of the first thermal baths was the "Acque Albule" in Tivoli, and the "Acque di Chianciano" in the homonymous town; the "Thermae" in the gulf of Naples; finally Pozzuoli and Ischia, two more places where it's possible to find important ruins of historical baths.

During the period of middle-age baths lost their social value in its hedonistic aspect, but the use of thermal water for human care had a large growth. In the period of Renaissance many writers testified about the thermal water qualities ,but the important discoveries end enhancements in this period were less relevant than in the middle-age period.

During the period between the XVIII and XX Centuries, thermal baths have an exponential growth and several new buildings were built. The thermal baths in this phase became a more complex system, receiving new functions like: hotels, café, garden, and mixing the classical scheme from the roman age with spaces coming from the oriental tradition. In this way the thermal baths became again a luxury place for a new elite thermalism. The Art Noveau architecture (called "Liberty" in
Italy) was really popular during that time among rich middleclass and so became also the most used style for this kind of buildings. Today the architecture of the thermal baths are a union of luxury spaces with classical and modern thermal medicine. The result is a building where human health, wellness, beauty and fitness collaborated for a large system with continuous innovations and research in technology solutions.

\subsection{The beginning}

The "Acqua della Salute " in Livorno born along the "Viale dei Condotti"; there are two different stories about the discovery of that curative water: legends and historical events. The legend tells: once upon a time in that plot of land emerged on the surface an unknown water and some cattle while grazing in this area have drunk the water and were afflicted by dysentery.

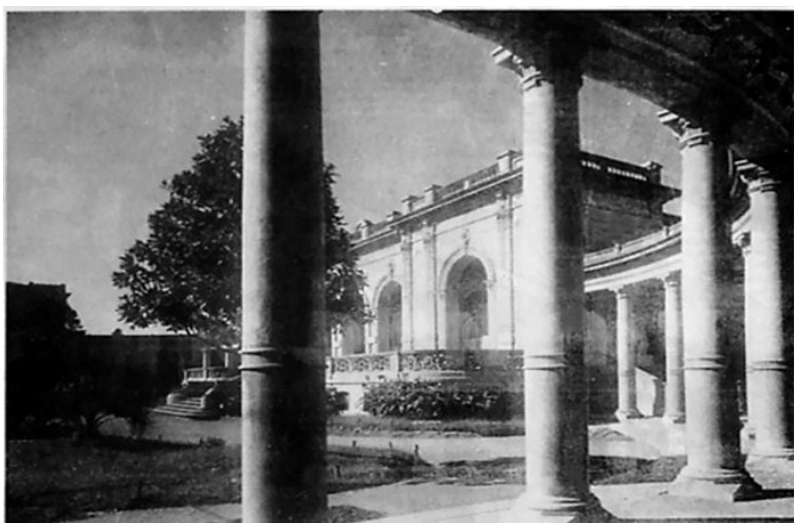

Figure 1: The "Terme del Corallo" before the abandon

After this fact the owners of that land decided to seek for the water. History tells that in 1854 there was a dry spell, and the families of the owners were in need of more drinkable water 
because of their growth. After two excavations they found water and the scientific tests proved that the water was drinkable and had purging features.

In the 1865 along the "Viale degli Acquedotti" the owners of another area, excavated the land and found a different water and they named it "Acqua del Corallo" (water of the coral). During the period from the 1854 to the 1893 , six different kinds of water were found, the curative property of these waters became famous; the hospitals near Livorno started using the waters for medical treatment. The popularity of the waters was the beginning for a new company, created by a group of persons with a robust fortune behind them, the name was "Società delle Acque della Salute" (literally: "The Health Water Company"). The company decided to protect the water in the ground building an underground system of walls; in the 1903 they decided to entrust Angiolo Badaloni with the task of realizing the new building named "Stabilimento delle Acque della Salute" (literally: "the Health Water Establishment").

The inauguration of the building was a grand event, people from far away went to visit the Art Noveau building. Livorno was decorated, citizen could appreciated and visit the thermal baths. Livorno during this period became a popular place for humancare with thermal water and was indicated as "Montecatini a mare" (Literally "Montecatini on the sea") with a direct recall to the name of "Montecatini Terme" a very famous town in Tuscany for its thermal baths.

The life in "Montecatini a mare" was studied from morning to evening; people spent in the "Stabilimento delle Acque della Salute" $15 / 20$ days, according to the treatment agenda. In the complex it was possible to have different activities, some kind of entertainment and to relax.

\subsection{The abandon}

About the events that caused the closure of the complex, there is not certain information. The building worked until 1936, the Second World War was one of the main cause. Livorno was strongly damaged by bombing, in the centre of the city remained safe only the $8 \%$ of buildings, while in the suburbs of $43 \%$ buildings were saved.

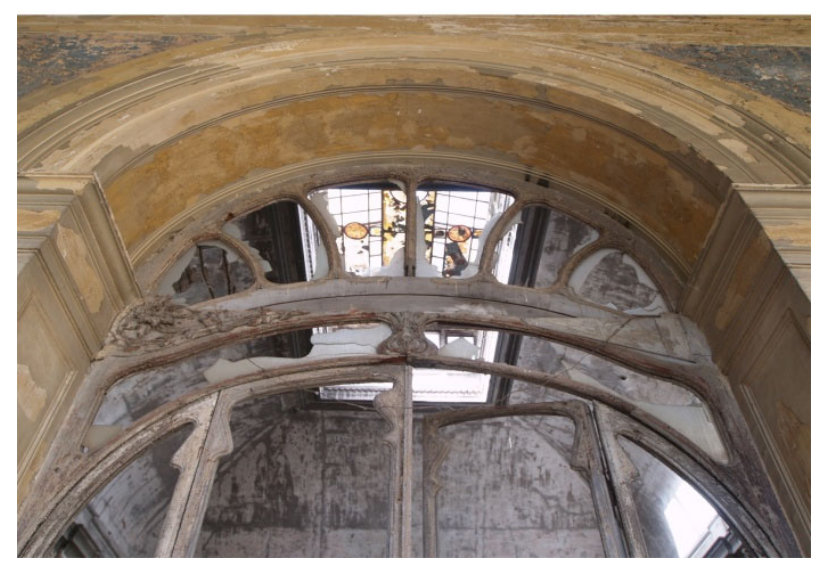

Figure 2: Entering the dance hall. Today.

The "Stabilimento delle Acque della salute" wasn't hurt, but obviously the affluence was strongly reduced.

Immediately after the Second World War there was an increase of the population caused by the return of soldiers, so in the 1947 the local Administration bought the area in the east side of the city and started to build housing.

This big growth of the city in this area (in the surroundings of the thermal baths) probably cause the pollution of the ground and destroyed the underground walls; the water was dispersed. After this the "Stabilimento delle Acque della Salute" changed its primary function into: disco; club.

The last use of the building was as a factory. In 1964 Livorno had the major number of bottling factories in Italy. The name of the society was S.T.I.B (Società Tirrena Imbottigliamento Bevande). The factory produced four different drink, the most famous was Coca-Cola.

In the 1967 Coca-Cola society bought S.T.I.B and after three years closed the factory. In the 1967 Coca-Cola society bought S.T.I.B and after three years the factory was closed.

\section{THE SURVEY}

\subsection{Collecting all the available archives and visiting}

There graphical maps and detailed information are quite poor about this monument. The main building is not easy to access, but it is possible to visit almost all of the lateral building, because it has been occupied by homeless but also by independent spirits in the past twenty years. Because of a minimal but working maintenance this two parts of the area aren't crumbling like the main monumental area, the work made by people living there was enough to preserve a minimum the conditions of the architectural elements.

The original drawings of the "Terme del Corallo" have disappeared, there are some drawing of sections of the dance hall dome in the civil archives in Livorno. Anyway there is no complete survey of the complex.

But some simple drawing can be a feeble trace but they can be enough to start some planning about a new survey.

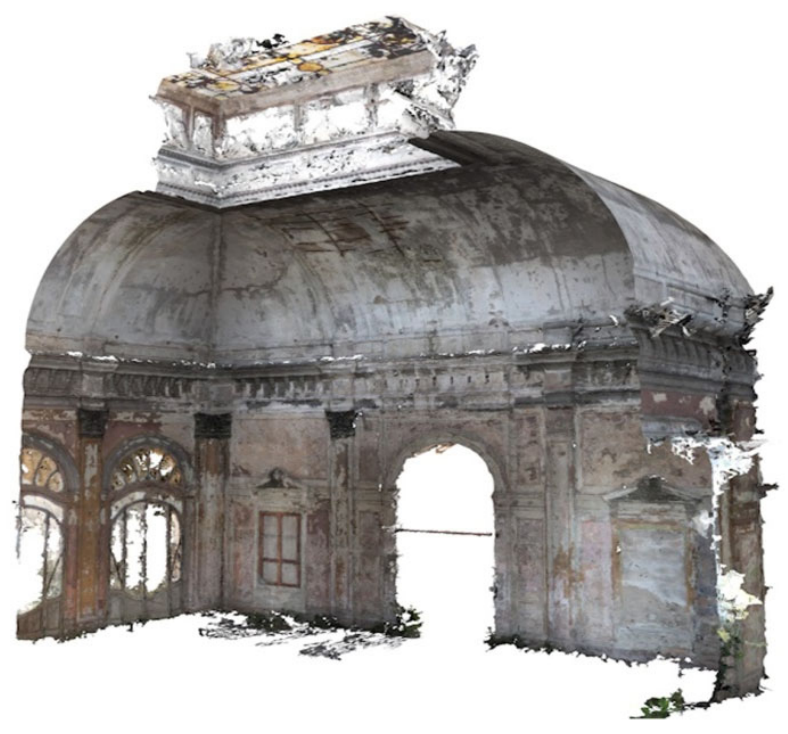

Figure 3: The dance hall, the first photo scanning result

\subsection{The digital survey}

The building is very complex to measure; there are many roofs and vaults near to collapse and so it is very difficult to use direct measurements. Some parts of the building aren't really safe at all: falling windows, falling plaster, the risk of a structural collapse from a vault, a ceiling, a floor.

These are problematic conditions and so it was chosen to survey the building using a medium range solution. Now it is worth stating that there was also the need to operate in a quick, economic and very efficient way, gathering geometrical and images of large and crumbling parts of the building, so a 


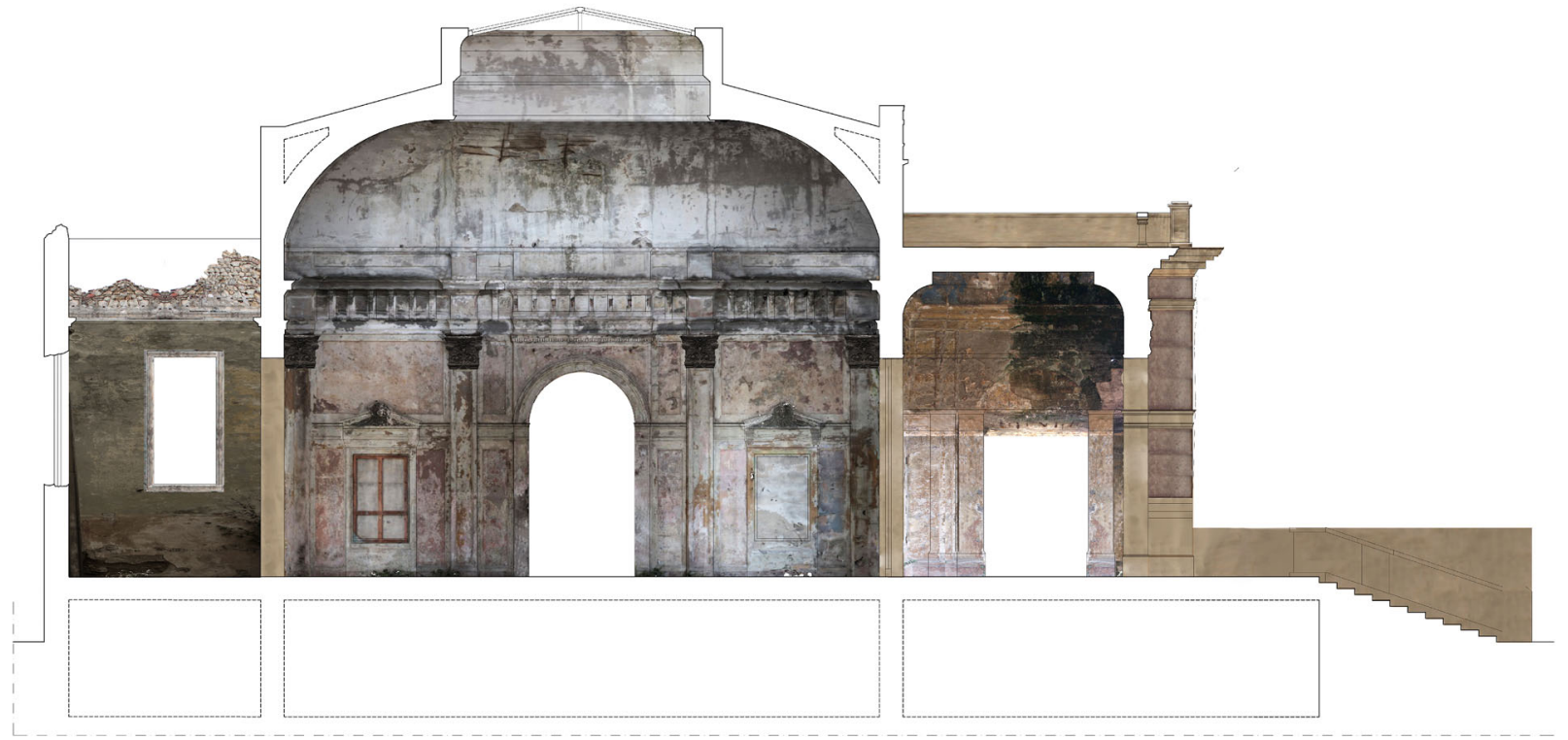

Figure 4: Section along the dance hall

expeditious photogrammetric solution appeared as a very good choice.

The AGIsoft Photoscan is one of the most recent and well working software for this kind of survey and so it was decided to centre the whole survey campaign on it.

The main needs to produce a good Photo scanning are: a stable tripod and a high definition digital camera. Photos should have a total depth of field; the image should be generated from a lens with an almost "hyperfocal" setting, with all the elements quite clear and readable.

It's important to photograph all the parts of the object; the methods is to divide the object with imaginary section plane, parallels of the surface to photo scanning.

The photographer should move along the imaginary line on the floor (projection of the section plane) with a regular interval with a distance between each position proportionate to the field of view. In each shooting station it is a good idea to take photos from the bottom to the top, paying a certain attention to the floor, while this part should be quite hard to obtain in the final model if not correctly documented. It's necessary to take photos of all interesting particulars to have a detailed Photoscan result. In this photogrammetric campaign two cameras were used: a Canon Eos 550D 18 megapixels SLR with a basic $18-55 \mathrm{~mm}$ Canon zoom lens and an Olympus E500 8 megapixels SLR with a superwide angle $9-18 \mathrm{~mm}$ Zuiko zoom.

To get a good quality in the Photoscan final model it is worth taking more photos than needed, while this might sound unnecessary, when it's time to create the model some more shots are always useful, a little difference in the point of view, a minimal difference in the quality of similar shots may produce a quite different result.

The further process is the loading of all the images in the software and the start the workflow to create the final digital 3D model of the surveyed space.

This phase can be quite long, because using the software is a time consuming process, starting from a first alignment, to the creation of the geometry to the completion of the process with the creation of the overall texture to be mapped on the mesh surface. The result will be a complete $3 \mathrm{D}$ digital model coming from the 2D information of the pictures; the final result is a three-dimensional polygonal surface with a texture applied on it. The texture is created by an union of the photos loaded in the software to start the whole operation.
Because of the possibility to export the model in the most common 3D digital models it is quite easy to bring it in any $\mathrm{CAD}$ and rendering environment and develop specific drawings and representations. In this work the main exchange format used were the PDF3D format (for quick view, checking and presentation) and the OBJ format with all the texturing converted into JPG images.

\subsection{Integrations and verifications}

The post processing of all the photogrammetrically generated $3 \mathrm{D}$ models was planned in order to use this survey to recompose and develop a coherent drawings of the main plan, of some meaningful sections and of all the main fronts of the building. All the information that obtained by photo scanning, became a part of the archives. Some minor direct measurement taken when it was possible and safe, were integrated to complete this task. A simple modelling process, based on the mesh coming from Photoscan was applied to produce the first draft result for developing all the final drawings: slicing the polygonal mesh into orthogonal parts all the base to produce plans and sections were quickly obtained.

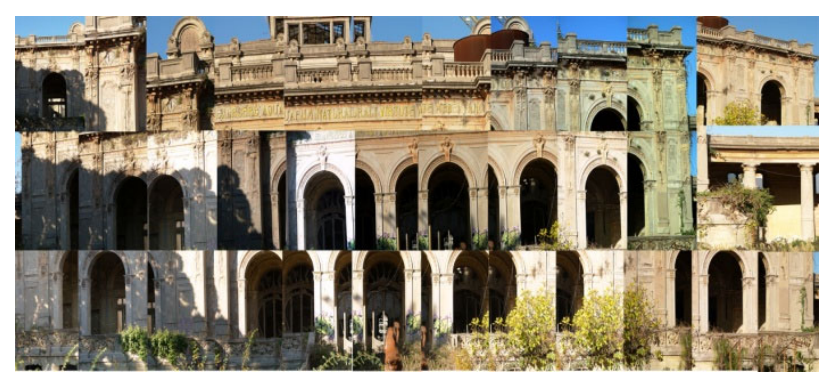

Figure 5: Shots for photo scanning from the front on the garden

Bringing high resolution rendering images in Autodesk Autocad it was quite easy to use them as a base to add and integrate the direct measurement. When the drawing wasn't enough detailed a direct reading of photos taken on each single interesting element was an important step to add details and complete the drawing with the needed quality. 


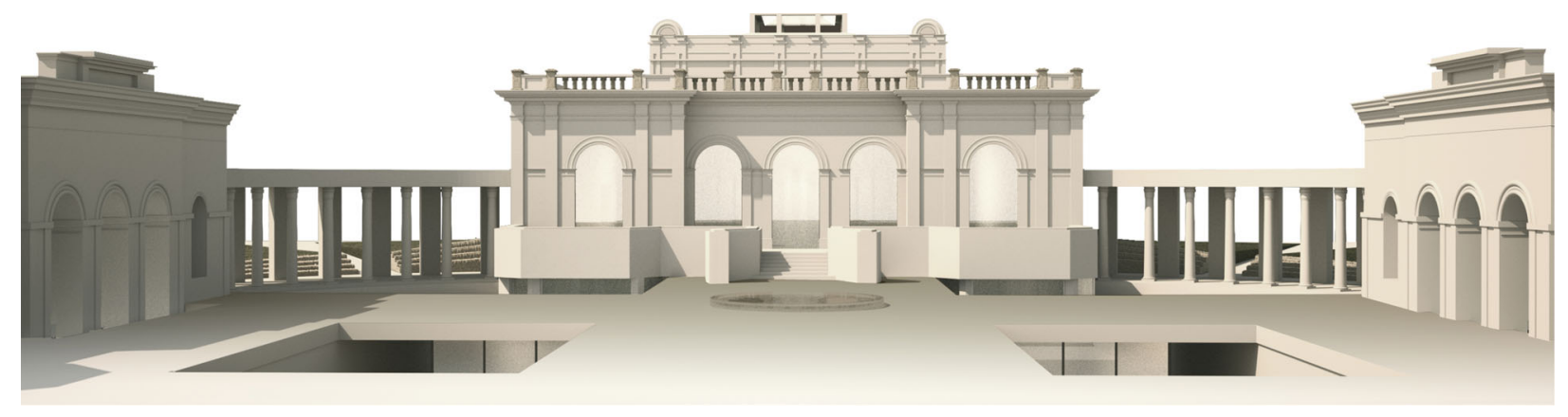

Figure 6: Digital 3D model of the front on the garden

When it was convenient some detail photos were filtered to compensate their perspective and proportioned before their use inside the CAD environment. Little by little a complete and detailed graphical documentation of the monument was completed. With a quite complete plan, main sections and main fronts. A first, useful, set of drawings after years of looking at the monument falling down one piece after the other.

\section{THE DREAM OF THE REBIRTH}

The idea is a complete restoration of the building bringing it back to its original function of thermal baths and adding to this main role some other important functions like: a café, a modern spa and a large conference hall.

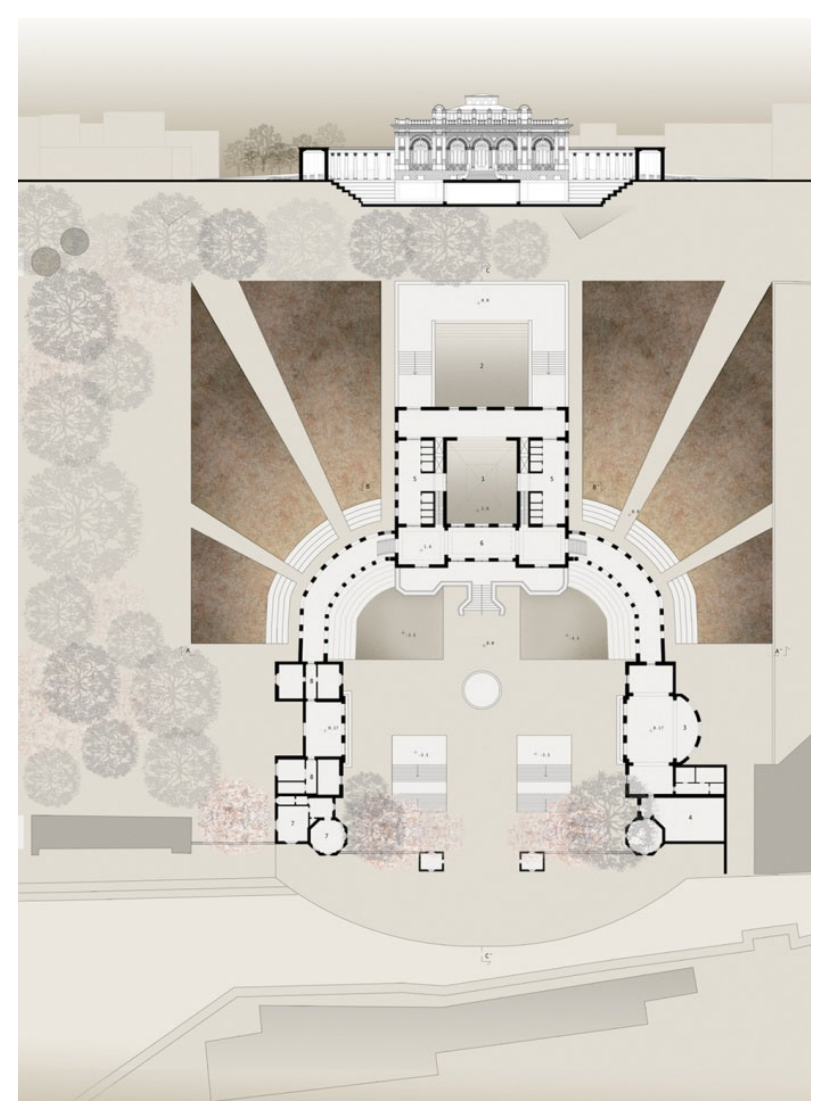

Figure 7: The dream of the rebirth, entrance level.

This choice was inspired by other example of restored thermal bath in Tuscany (Like the "Terme di Montecatini and the "Terme di Salsomaggiore"). In the project the plan recreate the original a " $\mathrm{C}$ " shape, it is composed by a central building and other two lateral ones. Inside the main building there is a dome that was built with reinforced concrete; the other two building has the same main front in the direction of the central square; a colonnade connects the three parts.

The building is characterized by a perfect symmetry. This main characteristic suggest a direction and underline also the importance of South-West front. This area was born as an East expansion of the main Livorno town and it doesn't have very meaningful design rules until the development of the "Terme del Corallo" settlement.

The choice of suggesting a square in front of the main entrance is guided by the will to create a place where it will be possible to appreciate the symmetry of the whole building and also to give an appropriate importance to the main entrance.

The project is aimed at preserving the historical shapes of the thermal settlement and it wants to recover all the historical decorations. For this reason all the new functions are placed underground. In the restoration propose the problem of lighting the underground space is solved excavating below the main colonnade following its same curvature.

The two symmetric excavations, together with the colonnade create a shape similar to the one of an amphitheatre; and the light can penetrate inside this space.

The main function of thermal bath is inside the central building of the complex, the restaurant and café are inside the building on the right side and finally the spa and office are in the left side. The suggested restoration is named "dream of the rebirth" because its will to recreate an almost lost monument, each day put this building even more behind any recovery possibility, but it still has the great fascination of the ruin and the great strength of something created to communicate beauty and welfare. So this is the focal point, the water, the place, the will of beauty and the mood of the place must recall the identity of the area, a certain spirit of the town, enhancing the sense of awesome spatial elements in front of the poor speculative housing developed all around the "Terme del Corallo".

\section{References from Proceedings and Books:}

Menicagli Di Batte S., 2000. Fatti e personaggi attorno alle Acque della Salute ovvero Storia di Montecatini a mare, Editrice l'informazione.

Piombanti G., 2003, Guida storica ed artistica della città e dei dintorni di Livorno, Arnaldo Forni Editore.

Bossaglia R., 1985, Stile e Struttura delle città termali, Nuovo Istituto Italiano D'arti Grafiche.

Bairati E., Riva R., 2001, Il Liberty in Italia, Laterza Editore. 
Giusti M. A., 1996, Le età del liberty in Toscana, Octavo Franco Cantini Editore.

Cagianelli F., Matteoni D., 2006, Livorno la costruzione di un immagine, Tradizione e modernità nel Novecento, Silvana Editoriali.

Faroldi E., Cipullo F., Pilar Vettori M., 2008, Terme e architettura, progetti, tecnologie, strategie, per una moderna cultura termale, Maggioli Editore.

D.I. Kosmopoulos, A. Doulamis, A. Makris, N. Doulamis, S. Chatzis, and S.E. Middleton, "Vision-based Production of Personalized video" Signal Processing: Image Communication, Elsevier Press, Vol. 24, No. 3, pp. 158-176. March 2009

Pasqualetti R., 2008, Architetture Livorno, Edizioni ETS.

Pasquinucci M., 1993, Terme Romane e vita quotidiana, Franco Panini Editore.

\section{References from websites:}

History of the "Terme di Montecatini"

http://www.termemontecatini.it/ accessed April 2012.

History of "Terme di Salsomaggiore"

http://www.salsomaggioreterme.com/ accessed April 2012.

A research of about Thermalism http://www.sld.cu/galerias/pdf/sitios/rehabilitacionbal/medicina _termal_y_termalismo.pdf accessed November 2011.

History of Livorno http://www.paolobodega.com/ accessed December 2011.

History of "Stabilimento delle Acque della Salute" http://www.lanazione.it/livorno/cronaca/2010/12/10/427188scandalo terme corallo.shtml accessed January 2012.

History of "Stabilimento delle Acque della Salute" http://iltirreno.gelocal.it/regione/2010/01/06/news/riaprite-leterme-del-corallo-lo-chiede-il-popolo-diinternet-1.1767550 accessed January 2012.

Art nouveau in Italy http://www.arteliberty.it/storia.html accessed February 2012.2008

\subsection{Acknowledgements and Appendix}

The operative group for the documentative survey of the "Terme del Corallo": arch. Valentina Fantini, prof. Giorgio Verdiani, arch. Mirco Pucci.

The photogrammetric survey was developed with the fundamental efforts of arch. Mirco Pucci.

The whole survey campaign was planned and developed in collaboration with Area3D Srl Livorno, a special thank to Massimo Gualandi and Alessandro Peruzzi from that company. 
